\title{
Analysis and Evaluation of Four Negative Characters of Championship Era (Jamasp - Soodabeh)
}

\author{
Behnaz Shahnavazi ${ }^{1}$ \\ ${ }^{1}$ Islamik azad university khash branch /Department of Persian language and literature, Iran \\ Correspondence: Behnaz Shahnavazi, Islamik azad university khash branch /Department of Persian language and \\ literature, Iran. E-mail: bshahnavazi60@yahoo.com
}

Received: June 22, 2013 Accepted: August 10, 2013 Online Published: August 15, 2013

doi:10.5539/ells.v3n3p96 URL: http://dx.doi.org/10.5539/ells.v3n3p96

\begin{abstract}
The Sage Abolqasem Ferdowsi is on of the first-grade stars of Iran Literature and Culture who became populated in historical past era by his worthwhile book, Shahnameh, and his extensively clear life was sank in a mist of gloom and unfamiliarity. Despite all the emphasis on avoiding bad behaviors and sin in national Shahnameh, many of the actors of it, even kings and heroes, who are made and processed by wishes and myths, are not defect-free and are infected somehow to sin. Even World Champion, Rustam, who is the main part of Ferdowsi' performance in Iran national epic, is finally killed by unfair tip and trick of his brother. This fact indicates the tangible nature of personalities in Shahnameh and the reason of their influence on peple. As, moral and educational perfections enable people reaching higher levels and vice versa, badness leads to afoul in whirpool of distruction. And Ferdowsi, parallel to narrative these stories has tried to write out the national epic via the most frightful tragedies and murderous and informative events, and at the end, beautifully visualizes his internal utopia and in order to mount the highest glory of ideal human esteem, reached the top mountain on which human knowledge and capability was created.
\end{abstract}

Keywords: Ferdowsi, negative personalities, Jamasp, Soodabeh

\section{Introduction}

The oldest book the points out the name of Ferdowsi and his immortal book, Shahnameh, is the history of Sistan of the half of the fifth century; and more detailed is Four Papers of Nezami Aroozi, which was essayed 550 Hijri, i.e., 1.5 centuries after Ferdowsi. Abolqasem Ferdowsi was born in 329 or 330 Hijri, the years in which Roodaki Samarghandi was turning down, in Toos, Gharie Baj (Baz). He was on ofe noblemen of Toos, known as "Peasants", and had many properties. His name and his father's was Mansoor-ben-Hasan and his nickname was “Abolqasem Ferdowsi” based on Sistan History and Four Papers.

Ferdowsi' Poem, Shahnameh, is one of the best belletristic and classic writings of world literature. Shahnameh is a treasure full of valuable gems of wisdom, advice, example, rhetoric and oratory of which Farsi language, Iranian race and humanbeing is proud. Ferdowsi has augmented the nationalism in Iranian' heart, by composing Shahname, praising the kings and heroes and stating the glorious history of Iran; since it contains the narrative history and the stories of ancestors of Iran and is counted as the family tree. Developing content, even around the time the study praised the investigation takes at least several projects. A Shahname' human, is a human tree, who runs roots to the depth in one hand and the head has a peak ascent in the other hand. This similarity of human and tree, is not only the creation of writer's mind, but, according to an iranian myth, the creation of human being has been via two rhubarb shoots and remind the similarity of hunan being with trees (Sarami, 2004: 29).

Stating historical and meaningful stories, Ferdowsi teaches wisdom and its great value for human being and also ethics and honesty, and guides and directs people and edificates them via helpful advices in beautiful lectures and far from personal interest.

\section{Review of Literatures}

As it was already mentioned so far no ther work has profoundly and independently analyzed antagonist characters in Shahname. This is true about all three eras of Shahname that are: 1 . Styre era, 2. Heroic era, and 3. Historical era.

The only work which has briefly analyzed thses aspect of Shahname is Devils in Shahname written by Nastaran 
Safari. In her work she has briefly analyzed and discussed the devils in Shahname but she hasn't discussed anything about the antagonist characters. That is the reason the scientific analysis and evaluation of these two characters is done by considering their mischieves and wrongdoings.

\subsection{Jamasb}

Jamasb is the name of a wise legendary man, who has been famous in knowledge and many stories were made by him. Second part of this name is Asb, which has been seen in many ancient Iranian names; and the root and definition of first part is not known clearly. Jamasb belonged to Hogvah family, and his brother was Farshooshtar, who were both the ministers, counselors and guides of Goshtasp. His wife was Porochista, who was Zarathustra' daughter and in contrast, Zarathustra's wife was Farshooshtar' daughter, Hoovey. Jamasb-nameh is in Pahlavi language and it is said that this wonderful Wiseman, like Nostradamus, has predicted the world events about 5000 years ago, some of which were raising three great prophets, Moses, Jesus and Mohammad (PBUH), (Mazd, Yasna. Encyclopedia, 230) and has named them "Red-Shepherd with Wand", "Sat on Doneky" and “Mehr-Tester” respectively (Kazazi, 2004: 405).

Regarding Jamasb' knowledge and predicting ability, in the translation of some Pahlavi texts has been mentioned that his knowledge has been so much that he knew the figure of rain drops. Jamasp is the strong, powerful, selfish cheater and indulgence clergy of Goshtasp court who was very familiar with astronomy and predictive techniques; so that such familiarity was the tool for his machinations in Goshtasp court as well, because he only thought of his own profit and all his thinking were in line with the demands of the Goshtasp devil wishes; and was mostly seeking greater comfort and indolence for his own in Goshtasp court. When Gorazm, cowardly slanders Esfandiar in Goshtasp court, Jamasp with all positions of influence, hears all swearwords, but says nothing for his interest; and Goshtasp, according to statements of Esfandiar' sinister, arrests him in captive iron and goes to Zabul for two years to take rest. Then, Turks utilize his neglect to attack the Iranian and offend Goshtasp, as the only way to suppress the Turks, is evoking Esfandiar; and when he decides to get help from invulnerable Prince, Esfandiar, who is innocently in prison for many times, finds nobody better than Jamasp to lure him:

Table 1.

\begin{tabular}{ll}
\hline It red the jamasb jahandideh & What more dydst lorasib \\
\hline Esfandiar told him go aheud & Call me and lets be friend \\
\hline The rise of the I Ip bgvysh & Cho read the letter set on mpay \\
\hline One job now hemi should & Wi thout you working so naida \\
\hline
\end{tabular}

$(887-891 / 126 / 6 c)$

Jamasp, in order to express serving Goshtasb and being afraid of ruining his mirth and wassail by Torkan war, recommends releasing Esfandiar from prison and when Esfandiar meets him after trump and suffering, talks with Jamasp and said that his father captured him innocent, by a poor excuse, rather than rewarding him for all fairness and self-sacrifice in the land of Seven Khan for Iran and its kingdom and freedom. Thus, Esfandiar asks Jamasp for solution:

Table 2 .

\begin{tabular}{ll}
\hline The wise gftash esfandiar & What andryan on my nose job \\
$(921-129 / 6 \mathrm{c})$ &
\end{tabular}

Jamasp, hears Esfandiar' words but thinking only on one thing, that is taking Esfandiar and encouraging him to go to war with the Turks, and satisfaction of Goshtasp. Therefore, recognizing the moral and behavoral characteristics of Esfandiar, tells him intriguing statements to promote his emotional feelings, then speaks regretfully on killing innocent Lorasib, his ancestor, to stimulate the hatred and revenge feeling of invulnerable hero: 
Table 3.

\begin{tabular}{ll}
\hline If you were such an amazing fa fate & Unfor tunately the king was looking \\
\hline Whe ther the heart is full of pain & The chaos and yellow rkhsargan no \\
\hline
\end{tabular}

$(9 1 9 - 9 2 4 \longdiv { 1 4 9 / 6 c ) }$

Analyzing Jamasp personality, it can be concluded that the main lines of his negative character is deception and intrigue, which is determined after the death of Esfandiar by Rostam and especially with Pshootan' reproaches; because he knew clearly that Esfandiar would be killed by Rostam and even knew the details of his life, but still encouraged him to battle with Torkan and going to Gostasb' palace. Even, when Esfandiar was ordered by Goshtasb to arrest Rostam, Jamasp knew that he would not be able to fight with Rostam and knew that it was the last battle of Esfandiar. He even was aware that his death was in Zabol and that was the last meeting of Esfandiar and Goshtasp; but he did not stopped Esfandiar and sent him to the war; that is why Pashhotan reproached him and said:

Table 4.

\begin{tabular}{ll}
\hline It was vrkh bgft the jamasp & I am a man who bdkysh bdzad \\
\hline The world do not know about th & The perrersity whoever did the blaze \\
\hline Qian feud be tween terrorism & This means that the hemi wife \\
\hline Donot know but bad hemi learn & The good the bad break tvkhtn \\
\hline I killed a big speech & All were killed when the big day \\
\hline King taught me the way to floss & The old way and the short and distor \\
\hline You said that yale in telligence & Rustam was noted on floor \\
\hline (1576-1583/316/6c)
\end{tabular}

The last selfishly predicting and policy making of Jamasp, after Esfandiar' death, is when Bahman, Esfandiar' son, becomes a tall and experienced champion and learns the best professions by Rostam; and as Jamasp knew that he would become the king after Goshtasp, suggests the king to write a kind letter to Bahman, in order to provide his own power in Bahman’ palace to live in leisure, either with Bahman or with Goshtasp, as the king:

Table 5.

\begin{tabular}{ll}
\hline Jamasp bdanst the good an the ba & The king dom is \\
\hline The hon orable king said to gosh & Did you have to look avalanche \\
\hline His legacy to the world that you & Esfandiar pain gsarndh \\
\hline
\end{tabular}

(1586-1589/317/6c)

As he was aware of his religious feelings, takes anti-religiousness of Torkans and their disrespect to Avesta and smoldering NooshAzar Fire-Place and killing clergymen as an excuse, and as knows that Esfandiar believes in Bahayi customs, says that you wouldn’t be forgiven by God if you don’t rise for helping religion:

Table 6.

\begin{tabular}{ll}
\hline The hare bad yazdanparast & Which were obtained dy the zand av \\
\hline Bkshtnd serenties the priests & Prstndh and choseh to buy \\
\hline Pean cain g g or g where the nj & Acceptable heve gvide \\
\hline 221-225/149/6c)
\end{tabular}


Then, remindes him the right of father on son and necessity of obeying the king’s orders, to promote Esfandiar to meet his father:

Table 7.

\begin{tabular}{ll}
\hline You know the boys father is an & Elder son of the father to make \\
\hline So go on bdaydt & He does whaterer padshahst oei \\
\hline
\end{tabular}

$(926-927 / 129 / 6 c)$

Since Jamasp couldn't convince Esfanidar to visit his father, with all deceits, talked on Farshidverd scars, his close friend, the story of how he was killed, so that the strength the naïve prince finally breaks and goes to Goshtasp port:

Table 8.

\begin{tabular}{ll}
\hline Kai told him world champion & If you are dark borough \\
\hline What to do if ever $\mathrm{f}$ word & It was always hot and the pain that $\mathrm{y}$ \\
\hline Evi lives spin out of the mavsh & The eyes tearful forgive oei \\
\hline
\end{tabular}

$(9 3 1 - 9 3 4 \longdiv { 1 3 1 / 6 c ) }$

\subsection{Soodabeh}

Sudaveh, or "Soodabeh", has been Sūtāpag in Pahlavi. It could be created of Sud + Aveh. Aveh or Abeh or Water, which has been used in the words like "Soodabeh", "Rudabeh" and "Mehrab", could be derived from Avesta' stem, Hep, whose synonym in Sanskrit is "Sep", meaning "keeping something, and caring about something" (Kazai, 2005: 498).

The second part of her name is "Sud", by the meaning of "profit" and "advantage", and totally the name means:

"the one who cares about profit: the one who thinks of her own profit" (Kazazi, 2005: 498).

The feature of Soodabeh with this name fits the stories of Shahnameh; because she was a capricious and selfish. "Monshizadeh knows this name as "Sau t apa", that is Indian, and believes that it may have derived from "saut" in Indian as "wife".

Mehrdad Bahari who links Soodabeh with mythes of productivity in Mesopotamia, measures this Hamavarani woman by Ashyar and knows her name as watery and luminous. He believes that this name has been derived from "sav" and guesses that its ancient Iranian name has been "Sut an apaka" (Bahar, 1996, quoted in Letter of Ancient: 498).

"Soodabeh, the wife of Kei-Kavus, who made incentives against Siavash" (Atabaki, 2000: 287).

Soodabeh, only daughter of Hamavran King, beautiful with the sun shining face, snare hair and a coddle girl who is the symbol of love, capricious, crime, seduction; and owns the splendor and glory which is just for the kings' wives, according to the ancient law. Kavoos, the king, heard narcissistic beauty of Soodabeh, falls in love with her and though the king of Hamavran tihghtly loves his daughter and does not have good relations with the Shah of Iran, but Soodabeh is so intrigued by the glory and dignity of Kavus the king that resists in front of his father:

Table 9.

$(108-106 / 133 / 2 c)$

\begin{tabular}{ll}
\hline s. zein told him nochoice & She is better today than sympathetic \\
\hline Where is the prince who was & Go boom will mahan hemi \\
\hline Zpyrnd angry with him why? & Who nshmrd happiness to sadness \\
\hline
\end{tabular}

Following the story of two lovers, a great war is run and for turning back Soodabeh an army of Barabrestan 
attacks Hamavran and when Kavus and his soldiers get arrested in a fortress, Soodabeh protests with messy hair and torn clothes:

Table 10.

\begin{tabular}{ll}
\hline So cho sawone of the latency & Translated into the following khosra \\
\hline The double hung lasso meshki & Glahn hazelnut color to give a blood \\
\hline Cayenne told the them to work & Men are praised for men \\
\hline Why not strap on jngsh & Which armor jamsh pun andbed? \\
\hline He sent the digs name & Plasm of the flower steadily poured \\
\hline Not separated from the $\mathrm{k}$ & And although she is lhd nhft \\
\hline K chu the strap should be pulle & The sinners bbayad my head cut off \\
\hline
\end{tabular}

$(169-179 / 137 / 2 c)$

After years of living with Kavus Shah, another fire of lust is burned; she reveals the modesty and privacy and falls in lover with her stepson, Siavash; accusing him with a terrible accusation, she holds a the field of a tragic and bloody war between Iran and Turan. Soodabeh meets him for the first time and falls in love with him:

Table 11.

\begin{tabular}{ll}
\hline Znagah on siavash please & Thoughts and his heart was filled br \\
\hline It was so that the top strings & And firy in the I ce nhdh \\
\hline
\end{tabular}

$(182-183 / 139 / 2 c)$

When Siavash refuses going to Soodabeh' back yard and tells his father that he does not tend to go towards there, Soodabeh finds another way to enter, she tries fooling Kavus and pretend that she wants to show the girls in the yard to him as it is the of his marriage, and wants to make the sisters happy of visiting their brother, Siavash; then Kavus forces him to go to the yard:

Table 12.

\begin{tabular}{ll}
\hline S the other day shgbyr & Iran brshah khramy taft \\
\hline Kai told him prince corps & The sun and the moon like you ndyd \\
\hline Sent to your yard & Sisters on their fghstan \\
\hline All the participants wore it stamp from & Heart is full of love and full of water \\
\hline
\end{tabular}

$(144-145 / 14 / 3 c)$

And when she was not successful of visiting Siavash in the yard, once again deceives in another way. She provides a party with a beautiful dress and wearing the royal crown; deals on makeup and calls Siavash to the party, and pretending the motherhood love, hugs him firmly and kisses him longingly:

Table 13.

\begin{tabular}{ll}
\hline Byamd fs and prayers brdsh & A long time in coming to the \\
\hline Hemi eyes and long kiss & It came from the kings journey \\
\hline
\end{tabular}

(198-199/17-3/18c)

In order to pretend herself innocent, she invited Siavash to her yard showing that he wants to marry with one of her girls: 
Table 14.

$(282-279 / 22 / 3 c)$

\begin{tabular}{ll}
\hline Ken is one of the vow trea & A few words from my mpych \\
\hline Cho is the prince of the world s & You want wy body and monvments \\
\hline The harm that comes to my nm & Love me like he distin gvished \\
\hline Now im standing be fore you & I have tons of sweet life \\
\hline
\end{tabular}

She rudly shouted that:

Table 15.

(284-283/22/3c)

\begin{tabular}{ll}
\hline What I want from you all com & The head of the animal you npychml \\
\hline Placed tight and gave her a kis & Surely remember the shame navr \\
\hline
\end{tabular}

Siavash obligedly marries with one of Soodabeh' daughters, but the dirty lust of Soodabeh does not decrease.

Table 16.

\begin{tabular}{ll}
\hline Should be kept staring s & Read the thoughts of great charm \\
\hline A lthovgh he is not my comma & They spin out of love of my life \\
\hline The good and the bad cander & Openly and involved the \\
\hline If I make him from bpychd & I let out the forum zhu \\
\hline
\end{tabular}

$(314-311 / 3 / 24 c)$

Finally, she lays her guilty wish with Siavash and frightened him of the unfavorable consequence of the event:

Table 17.

\begin{tabular}{ll}
\hline One happy now in my final & Forgive my younger days \\
\hline Fur ther more the amount of da & Come on crown and some times ray \\
\hline Otherwise the bpychy under $\mathrm{m}$ & I promise you the bad tarzan \\
\hline I think you lost kingdom & Dark eyes are on king \\
\hline
\end{tabular}

(327-324/3/25c)

But the restraint and piety Siavash refuses to betray his father. This causes the flaming fire of revenge burns more in Soodabeh' heart; she crashed her face, cut her dress and skirt and tried to remove the young prince with the sin of slander with distressed state:

Table 18.

\begin{tabular}{ll}
\hline I told him the secret of my hear & Bgftm malice ous hidden from you \\
\hline You amaze me that you can ex & Rana to the wise gvy \\
\hline Po not clean hands and clothes & There will be two hemi nail scissor \\
\hline Came the cry from the yard & Fghansh came from the porch to the al \\
\hline
\end{tabular}


And roaring and moaning and screaming called the king and others to her house:

Table 19.

\begin{tabular}{ll}
\hline Khrrshyd in s oei & Water is poured hemi hair \\
\hline Siavash said kamd bed & Rast on hold and hung tough \\
\hline The officer byndakht meshkin fam & Chuck was so involved in my rig \\
\hline
\end{tabular}

$(345-347 / 27 / 3 c)$

Since her deceptions does not affect any more, she asked a woman to help her finding a new charm:

Table 20.

\begin{tabular}{ll}
\hline It invoved a search option ugly & Zkynh new tree slant board \\
\hline She was a woman entrvsted wit & It was full of magic and color of text \\
\hline It was expensive and involved i & Hemi was barely out of high \\
\hline Bgshad around the resort and zhu & I first started pymant center \\
\hline Chow trade agreement is that it & Do not talk about this in remembranc \\
\hline One pharmacist kane bfkhy & Money and mystery poor break me \\
\hline But all of cayenne and a numbe & This is my bchgan blaze \\
\hline To say that these are from k & Such dead hands ahrymnnd \\
\hline Cayenne is not the correct siav & The resort has byaydt search \\
\hline Greene king uncharacter is tic sight of my & I stay away from the darkand zgah \\
\hline
\end{tabular}

Thus, the cunning woman lay down her children; Soodabeh assumes herself as sick and calls Kavus to her yard to present him her fake and treacherous show, pretending that Siavash has caused this terrible tragedy:

Table 21.

$$
\text { Cho was adark night a woman dr } \quad \text { Zhu bftad gvys who ahrmn }
$$

Kavus Shah that got the subject of sceneries of Soodabeh, found the only way calling the astronomers and augurs solve the problem and asked them whether or not these guys are of Soodabeh. After a while, working on the stars and some professional deeds about this, they came to Kavus Shah and told him that the children where of the whitch woman and awared him that Soodabeh was guilty. Kavus decided to fire the bow, through to prove her guilt or innocence, but Soodabeh with bad behavior and some excuses wanted him to ask Siavash passing fire.

Finally, Siavash was chosen to pass fire. The fire was great as a mountain, but Siavash trusted GOD and asked GOD to exonerate him. Then he entered fire while the frames coming from everywhere.

Then, Siavash passed the fire successfully.

It was here that the guilt of Soodabeh and innocence of Siavash became evident; she did not remain quiet and in order to escape the heavy punishment, in an interview with Kavus, claimed that rescue of Siavash has been due to charm and magic of Zaal.

To punish Soodabeh for all these deceptions, which finally led to tramp of Siavash and pessimism of Kavus to him, and even after various adventures leading Siavash to quarter Afrasiab, jelousy of Garsivaz in Tooran, death of Siavash and Great war of Iran, the world champion, Rustam, attacks Kavus' palace furiously and arrests Soodabeh in a terrible condition and takes her down from the position of kingdom to the ledger of revenge and 
terminates her shameful life with dagger.

Soodabeh, given that her experience in the Shahnameh is not pleasant, is Most Evil Woman of all ages in this book. After marriage, she initially is loyal with Kavus, as when her father, King of Hamavran, plans to arrest Kavus, she secretly notices her husband of all cases, and when Kavus is captured by the king of Hamavaran via his own insaneness, she becomes his sweetheart and sympathetic in prison and cries a lot for his problem. But this Soodabeh, the lover, behaves incredibly and totally different with before, falls in love with her stepson, and treats a forbidden love in her heart. But when she does not achieve what she wants, starts trick and deception and even spectacles dying of poor young in fire. But GOD wanted that Siavash comes alive and successful out of fire, but the consequent of this fake love and deceptions was killing Siavash, the champion, and ruining his life. Because, at the same time, Toranian army, with Afrasiab as the leader, threatened Iran again. Siavash, in order to get far from the queen, asked his father to govern Iran' army since he did not come back to his father and also was afraid of Soodabeh. Toranian, who felt they would lose, suggested reconcile and accepting Iran' orders, but Keikavus did not accept and Siavash, afraid of going to his father and Soodabeh' traps, went to Tooran and Afrasiab accepted him happily. But he finally was kille in Tooran in a very brutal way. All these problems were the results of devil behaviors and lust of Soodabeh and foolness of Keikavus who could not solve the challenge between his son and his wife.

\section{The Importance of Study}

Every literary and research study has major and minor objectives which show the importance and values of it.

The main objective in this study is the analysis of two unscropulous antagonist characcters in Shahname. In order to show their negative characterization, I tried to anayze their mischieves and immoral behavior from different aspects.

The most important literary act in the first place is to narrate the related story of each charater's mischieves while introducing him. This is clearly done through presentation of poems and examples from the text. The narration increases both the values of a literary work and understanding of the readers. Another impoetance of this study is that no other work has independently provided any analysis of these two chararcters as well as that of this study.

\section{Research Methodology}

The research methodology in this study is qualitative. The main story has been extracted from shahname and so many handouts have provided the notes from it. These notes have finally been organized and the fremwork of this study and the story have been stablished based on them.

\section{Conclusion}

Shahnameh is the national assurance, courage, persistence, and pride. Through writing Shahnameh, Ferdowsi, could take Persian language to the pinnacle of popularity. The base of ancient characterization in it is on dividing to good and bad characters. Nowadays, this method, i.e., creating with and black characters from beginning to the end, is not done, and any character is a blend of good and bad characteristics. Among these personalities, in champion part of the book that has been written about kings and famous people there are two characters, called Soodabeh and Jamasp. Soodabeh is a princess and very famous, and Jamasp is a powerful minister, but incentive. Both of them are of the main factors of the murder of the princes such as Siavash and Esfandiar, especially Soodabeh who shamelessly and insolencely provided a bad doom for Siavash and Iran. In this paper, we have tried to review the most significant behaviors according to Shahnameh with examples.

We hope that this little drop of the sea of Shahname of Ferdowsi is accepted by the lovers of literature and the researchers of Shahname; and I apologize for any defects.

\section{References}

Abolghasemi, M. (1995). After this, I'm not Going to Die (Papers of Internationl Congress on Ferdowsi). Tehran: Tehran University.

Abolghasemi, M. (1997). The History of Persian Language. Samt, Tehran.

Akbarian, M. E. A. (1997). Shahname, the Great Cultural Phenomena in Global Civilization. Iran Centre of Studies.

Akbarian, M. E. A. (2005). Shahname of Ferdowsi (Critical Text of Moscow version). Tehran: Ghatreh.

Alborz, P. (1990). The Glory of Shahname in Cultural Mirror and Ethics of Champions. Behine, Alzahra Uni.

Amoozgar, J. (2004). The History of Mythology. Samt, Tehran. 
Atabaki, P. (2000). Dictionary of Shahname (Vocabulary Description, Idioms, Names and Places).

Bahar, M. (1990). Bendahesh. Tehran: Toos.

Bondari, Esfahani F. (2001). Shahname of Ferdowsi (T. B A. Ayati, Trans.). Tehran: The Council of Cultural Works and Concepts.

Dehkhoda, A. A. (1993). Dictionary. Tehran: Tehran University.

Haeri, J. (2004). Women of Shahname (Research from AzarGashb to Homay). Tehran: Yond no.

Hamidian, S. (2004). A View on Thoughts and Art of Ferdowsi. Tehran: Nahid.

Khaleghi, Motlagh J. (1993). Ancient Flowers of Suffer (Papers about Shahname). Tehran: Markaz.

MacKenzi, D. N. (1994). Small Pahlavi Dictionary (M. MirFakhrayi, Trans.). Tehran: Research Institute of Humanitary and Cultural Studies.

Nazeri, N. (1990). Advices of Ferdowsi in Texts of Stories. Mashhad: Javidan Kherad.

Poor, Davood E. Gasaha Notes. Tehran: Tehran University.

PoorKhaleghi, Chatroodi M. (2001). The Tree of Shahname (The Cultural and Symbolic Values of Tree in Shahname). Mashad: Astan Ghods Razavi.

Rahimi, H. (2001). Epics of Shahname. Tehran: Pajoohe.

Rastegar, Fasayi M. Image Creation in Shahname (Evaluating the Similes and Metaphors). Shiraz: Farhang Mehr.

Sotoodeh, G. R. (2000). Dictionary of Shahname' Names. Research Institute of Humanitary and Cultural Studies. Yasna. Tehran: Tehran University.

\section{Copyrights}

Copyright for this article is retained by the author(s), with first publication rights granted to the journal.

This is an open-access article distributed under the terms and conditions of the Creative Commons Attribution license (http://creativecommons.org/licenses/by/3.0/). 